\title{
Labial Enamel Thickness of Chinese for Porcelain Laminate Veneer
}

\author{
Ker-Kong Chen ${ }^{1}$, Wei-Jie Lin', Tatsuo Ooki', \\ $\mathrm{Si}-$ Zhen $\mathrm{Shi}^{2}$ and Masamichi Terashita ${ }^{1}$ \\ ${ }^{1}$ Department of Operative Dentistry (Chief: Prof. Masamichi Terashita) \\ Kyushu Dental College, Kitakyushu, Japan \\ ${ }^{2}$ Department of Pediatric Dentistry (Chief: Prof. Si-Zhen Shi) \\ Dental School, Tongji University, Shanghai, China
}

Accepted on October 25, 2002.

\begin{abstract}
The labial enamel thickness of the maxillary central incisor, lateral incisor and canine of Chinese teeth obtained from Shanghai was measured for serving as a guide for porcelain laminate veneer restoration in China.

The enamel reduction amount in the upper central incisor can be $0.3 \mathrm{~mm}$ at the cervical third region and then increased to $0.5 \mathrm{~mm}$ toward the incisal edge the same as the guidance reported for Japanese. The enamel thicknesses of lateral incisor and canine were thick enough to be $0.5 \mathrm{~mm}$ from the middle thirds to the incisal edge the same as that of central incisor, but thinner at the cervical thirds as compared with the central incisor, which suggests that the enamel at the cervical region is better to be reduced within $0.25 \mathrm{~mm}$ in order to avoid exposure of the dentin.

The mesial enamel thickness and the labial enamel thickness showed a significant correlation at both the middle third portion and the cervical third. This result suggests that the labial enamel thickness can be predicted from the mesial enamel thickness obtained by the X-ray photograph.
\end{abstract}

Key words: Labial enamel thickness/Porcelain laminate veneer/Maxillary anterior teeth

\section{Introduction}

The esthetic requirement in dental field has been increased due to the more aggressive concern with the tooth color from patient. A prominent tooth discoloration is often one of the reasons that patients come to the clinic for treatment. Schwachman (1956) ${ }^{1)}$ pointed out that the tooth discoloration could be caused by the incorporation of systematic tetracycline into tooth structure. In China, a great amount of tetracycline was medicated in 1970 s that 
caused a high ratio of tetracycline-stained teeth as a side effect in the thirties' age group than other age groups now. Some psychological problem may also be caused from the esthetic point of view as reported by Davis et al. $(1998)^{2)}$. Hosokawa et al. (1993) ${ }^{3)}$ reported that $89.4 \%$ of the patients performed with porcelain laminate veneer had a chief complaint of tooth discoloration. It means that the problem of esthetic disorder caused by discoloration can not be ignored. The porcelain laminate veneer technique and bleaching technique are considered as methods for solving this kind of problem. In fact, porcelain laminate veneer is a definitely effective method for solving this problem no matter how the discoloration degree may present ${ }^{4-8}$. This technique reduces only a thin layer of the enamel, and cements the fabricated veneer to solve the esthetic problem. To gain the most stable and greatest adhesive strength from tooth, the best way is to have a layer of enamel left for acid etching to obtain the desirable bonding strength and also have no dentin exposure during preparation in order to prevent pulp irritation. Therefore, the thickness of enamel is an important factor regarding the success of porcelain laminate veneer. There is still no report concerning the labial enamel thickness of Chinese that can be used as a guide before preparation yet. It is important to realize the available labial enamel thickness of Chinese in order to spread out this technique in China.

This study using the method reported by Chen et al. (1988) ${ }^{9)}$ was to measure the labial and proximal enamel thickness of the Chinese anterior teeth at eight points in order to realize the reducible enamel thickness for providing a guide in porcelain laminate veneer preparation.

\section{Materials and Methods}

The intact and caries-free extracted maxillary anterior teeth used in this study were provided from dental college of Tongji University in Shanghai. These teeth included central incisor, lateral incisor and canine with ten teeth for each kind of tooth.

The measuring method was in accordance with Chen's method (1988) ${ }^{9)}$ with three measuring points added. Each tooth was embedded by the embedding polyester acrylic resin (Refine tech, Tokyo, Japan) and then sectioned parallel to the tooth axis through the middle of the crown by a low speed diamond disc (Isomet). Four points of the labial enamel thickness were measured by a measuring microscope (Fig.1). I stands for the point toward gingiva $0.5 \mathrm{~mm}$ apart from DEJ, F means the mid-point between DEJ and CEJ, C2.0 means the point toward incisal edge $2 \mathrm{~mm}$ apart from $\mathrm{CEJ}, \mathrm{C} 1.5$ means the point toward incisal edge $1.5 \mathrm{~mm}$ apart from CEJ. Four points of the proximal enamel thickness on each tooth were also measured as shown in Fig. 2. $\mathrm{M}$ and $\mathrm{D}$ are the mesial and distal enamel thickness when the tooth specimen was cut through the middle points of DEJ and CEJ on mesial or distal surface, respectively. M1.5 and D1.5 were the mesial and distal enamel thickness when the tooth specimen was cut through the points $1.5 \mathrm{~mm}$ apart from CEJ toward the incisal edge on proximal surface.

Those data obtained from labial surface and proximal surface were used for statistical 


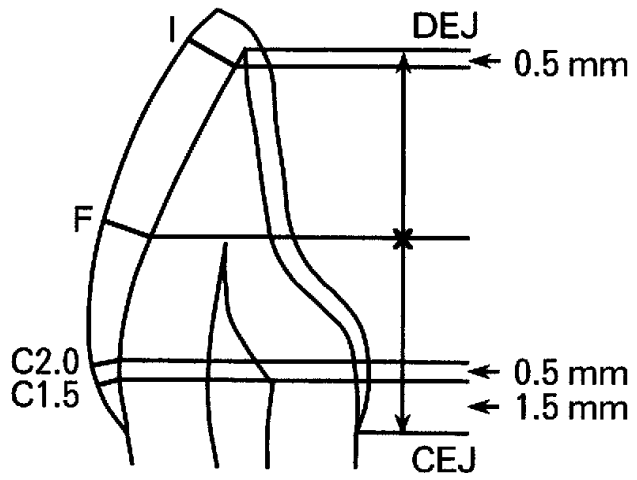

Fig. 1 The enamel measuring points on labial surface.

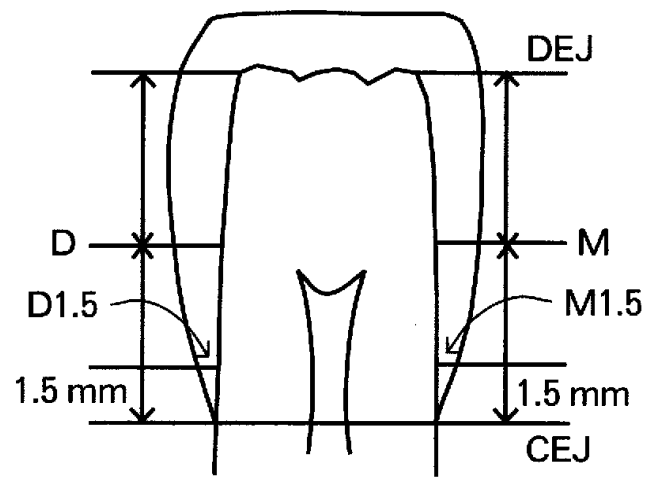

Fig. 2 The enamel measuring points on proximal surface.

analysis, Fisher's test and correlation.

\section{Results}

Table 1 and 2 show the result of the enamel thickness measured at eight measuring points of the maxillary anterior teeth.

Regardless of the kinds of tooth, the labial enamel thickness obtained at I and F was more than $0.7 \mathrm{~mm}$ whereas that obtained at $\mathrm{C} 2.0$ and $\mathrm{C} 1.5$ decreased to nearly half of the former. The enamel thickness measured at $I$ in canine was the thickest $(1.1 \mathrm{~mm})$ in this study. The enamel thickness measured at $\mathrm{C} 2.0$ and $\mathrm{C} 1.5$ in lateral incisor presented to be the thinnest, which did not exceed $0.4 \mathrm{~mm}$. Except the mid-points ( $M$ and $D$ ) of canine, the mesial enamel thickness tended to be thinner than the distal enamel thickness either at the mid-point or $1.5 \mathrm{~mm}$ above the CEJ.

Table 1 Labial enamel thickness of maxillary anterior teeth

\begin{tabular}{lcccc}
\hline & \multicolumn{1}{c}{} & & (mm) \\
\hline Central incisor & $0.91(0.10)$ & $0.76(0.15)$ & $0.49(0.09)$ & $0.43(0.07)$ \\
Lateral incisor & $0.99(0.10)$ & $0.74(0.09)$ & $0.40(0.10)$ & $0.31(0.07)$ \\
Canine & $1.17(0.13)$ & $0.96(0.22)$ & $0.41(0.14)$ & $0.34(0.13)$ \\
\hline
\end{tabular}

Table 2 Proximal enamel thickness of maxillary anterior teeth

\begin{tabular}{lcccc}
\hline \hline & $\mathrm{M}$ & $\mathrm{D}$ & $\mathrm{M} 1.5$ & $\mathrm{D} 1.5$ \\
\hline Central incisor & $0.76(0.14)$ & $0.78(0.15)$ & $0.41(0.16)$ & $0.48(0.10)$ \\
Lateral incisor & $0.69(0.09)$ & $0.74(0.07)$ & $0.38(0.12)$ & $0.41(0.13)$ \\
Canine & $0.87(0.12)$ & $0.82(0.22)$ & $0.38(0.12)$ & $0.41(0.15)$ \\
\hline \multicolumn{5}{l}{} \\
\end{tabular}




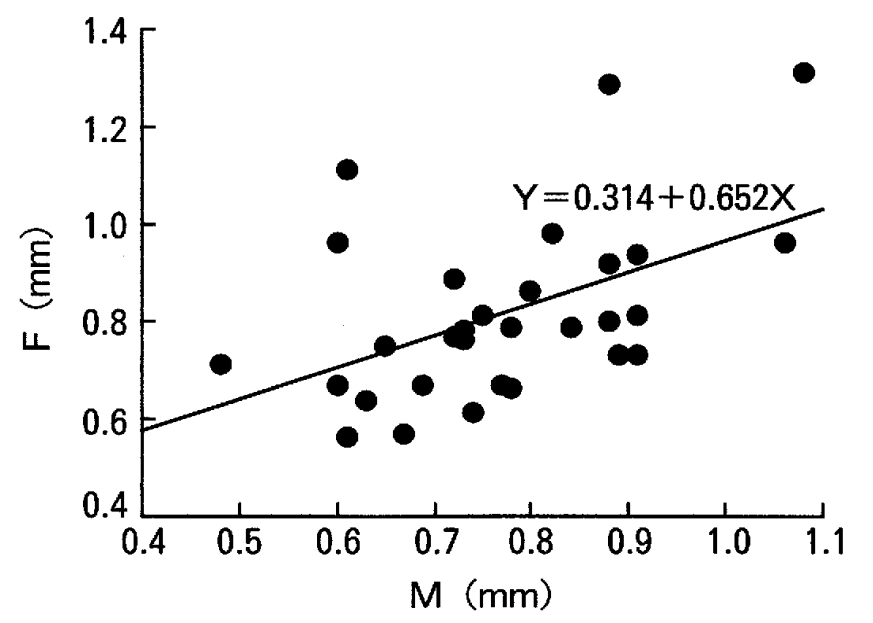

Fig. 3 Relationship between $F$ and $M$ of total teeth.

Comparing the labial enamel thickness and the proximal enamel thickness of all measured teeth, a positive correlation and statistical significance $(\mathrm{p}<0.01)$ were recognized among $\mathrm{F}$ and $\mathrm{M}, \mathrm{C} 2.0$ and $\mathrm{M} 1.5$, C1.5 and M1.5

(Fig. 3-5).

\section{Discussion}

It is well known that porcelain laminate veneer preparation should be performed within the enamel because not only the enamel can provide the most stable and strongest adhesive strength for the veneer to adhere on it but also the dentin once labial enamel thickness can be predicted before the preparation, a layer of enamel can be maintained for providing a firm adhesion and the exposure of dentin can also be avoided after the preparation. It is one of the important reasons to realize the enamel thickness in order to make this technique successful. This investigation was, therefore, to measure the labial enamel thickness of Chinese maxillary anterior teeth for offering a guidance in the porcelain laminate veneer preparation in China.

According to the measured data, any of maxillary anterior teeth would possess a labial enamel thickness at least $0.7 \mathrm{~mm}$ from the middle portion to the incisal edge which indicates that more than $0.5 \mathrm{~mm}$ enamel thickness can be reduced during preparation. This is coincident with those reported by Chen et al. $(1988)^{9)}$ and Fukushima et al. $(1991)^{12)}$. 
The incisal portion of canine was thicker than the other two kinds of teeth that provide a possibility of reducing more enamel when there is a necessity to emphasize or change the tooth color. The average labial enamel thickness of these teeth at $\mathrm{C} 2.0$ was $0.4-0.5 \mathrm{~mm}$ and became thinner at $\mathrm{C} 1.5$ to $0.3-0.4 \mathrm{~mm}$. Especially half of the lateral incisors and canines measured showed less than $0.3 \mathrm{~mm}$ at $\mathrm{C} 1.5$ and the value measured at $\mathrm{C} 1.5$ was smaller than that reported by Fukushima et al. $(1991)^{12)}$. It is apparent that if the reduction amount at cervical portion of lateral incisor or canine of Chinese is still maintained at $0.3 \mathrm{~mm}$ as reported so far, a high risk of dentin exposure will occur during the veneer preparation. Therefore, it is suggested that the reducible enamel thickness of lateral incisor and canine of Chinese near the $\mathrm{CEJ}$ may have to be performed thinner. In other words, the enamel amount of preparation at the cervical convex $(\mathrm{C} 2.0)$ is suggested to be $0.3 \mathrm{~mm}$ and then gradually reduces to $0.25 \mathrm{~mm}$ as toward the CEJ with an ending of chamfer margin. This preparation still preserves the principle of keeping a layer of enamel left for a firm adhesion. It is reported that the use of the dentin bonding system, especially the primer, can not only increase the bonding strength of veneer to dentin ${ }^{13-14)}$ but also prevent the fracture risk further when the cervical dentin is exposed accidentally and treated without a dentin primer $^{15)}$. It is therefore suggested that an attention should be paid to the cervical portion in preparing Chinese anterior teeth in order to avoid the occurrence of pulp reaction after dentin exposure and the accompanying complicated procedure for adhesive purpose.

The mesial enamel thickness seemed to be smaller than the distal enamel thickness at the same position; however, the mesial surface showed a strong and significant correlation with the labial surface than the distal surface $(p<0.01)$. In addition, the mesial enamel thickness was close but a little smaller than the labial enamel thickness at M and F or C2.0 and M1.5. It suggests that the labial enamel thickness can be predicted from the mesial surface in clinic, particularly once the enamel thickness at M1.5 is measured by a radiograph before tooth preparation ${ }^{16)}$, the high risk potentiality of dentin exposure at the cervical region of canine may decrease to a low degree.

Most of the measured enamel thickness in this study are proved to be nearly the same as those data reported ${ }^{9,12,17)}$ although the cervical regions of both lateral incisor and canine may have a higher possibility of dentin exposure. It is important to realize that a successful porcelain laminate veneer restoration may be affected by an appropriate preparation through a confirmation of the enamel thickness that can be predicted before treatment.

\section{Conclusion}

The labial enamel thickness of maxillary anterior teeth measured from Chinese in Shanghai can be concluded as follows:

1. The enamel thickness from middle thirds to the incisal edge can provide at least $0.5 \mathrm{~mm}$ for reduction.

2. The cervical thirds of central incisor can provide $0.3 \mathrm{~mm}$ although the cervical thirds of lateral incisor and canine should be limited to $0.25 \mathrm{~mm}$ to avoid exposing the dentin. 
3. The positive correlation among $\mathrm{F}$ and $\mathrm{M}, \mathrm{C} 2.0$ and $\mathrm{M} 1.5, \mathrm{C} 1.5$ and $\mathrm{M} 1.5$ suggests that the enamel thickness can be predicted from mesial surface by means of X-ray photograph.

\section{References}

1) Schwachman, H. and Schuster, A.: The tetracyclines applied pharmacology. Pediatr. Clin. North Am. 3: 295-303, 1956.

2) Davis, L. G., Ashworth P. D. and Spriggs L. S.: Psychological effects of aesthetic dental treatment. J. Dent. 26: 547-554, 1998.

3 ) Hosokawa, F., Chen, K. K., Ota, T., Shono, Y., Inokuchi, Y., Manabe, Y., Ogawa, T. and Terashita, M.: Clinical observation of porcelain laminate veneer for 1 to 6 years. Japan. J. Conserv. Dent. 36 (Autumn Issue): 18, 1993. (in Japanese)

4) Calamia, J. R.: Etched porcelain facial veneers: A new treatment modality based on scientific and clinical evidence; New York J. Dent. 53: 255-259, 1983.

5 ) Nagano, M., Terashita, M., Ogawa, T., Mori, T., Hsiao, Y. H., Kawakita, S., Chen, K. K., Wada, M., Inokuchi, Y. and Kawakami, M.: Porcelain laminate veneer: Clinical procedure and its problems. J. Kyushu Dent. Soc. 41: 1262-1269, 1987. (in Japanese)

6) Harley, K. E. and Ibbetson R. J.: Anterior veneers for the adolescent patient: 2. Porcelain veneers and conclusions. Dent Update 18: 112-6, 1991.

7) Araujo E., Oda, M. and Santos, J. F.: Porcelain veneers; Rev. Odontol. Univ. Sao Paulo 4: 265-268, 1990.

8 ) Small, B. W.: Porcelain laminate veneers. J. N. J. Dent. Assoc. 56: 62-3, 1985.

9) Chen, K. K., Shono, Y., Ogawa, T., Terashita, M. and Kobayashi, S.: Tooth preparation for porcelain laminate veneer Par 1 reducible facial enamel thickness in upper central incisor. J. Kyushu Dent. Soc. 42: 432-435, 1988. (in Japanese)

10) Pashley, D. H.: Dynamics of the pulpo-dentin complex. Crit. Rev. Oral Biol. Med. 7: 104-133, 1996.

11) Mjor, I. A. and Odont, D.: Pulp-dentin biology in restorative dentistry. Part 2: initial reactions to preparation of teeth for restorative procedures. Quintessence Int. 32: 537-551, 2001.

12) Fukushima, M., Ishikawa, K. and Iwaku, M.: Tooth preparation for laminate veneers. Japan. J. Conserv. Dent. $34: 127-130,1991$. (in Japanese)

13) Nakamura, T., Miyamae, M., Koh, N., Hino, T. and Maruyama, T.: Adhesive strength between teeth and resin cements for porcelain laminate veneer. J. Osaka Univ. Dent. Sch. 32: 21-26, 1992.

14) Chen, K. K., Ogawa, T., and Terashita, M.: Dentin primer application on porcelain laminate veneer restoration. Second International Congress on Dental Materials: 247, 1993.

15) Chen, K. K., Tajima, K., Kozono, Y., and Terashita M.: Dentin primer application to exposed dentin for porcelain laminate veneer. J. Dent. Res. 72 (Special Issue \#1596): 303, 1993.

16) Chen, K. K., Manabe, Y., Ogawa, T., Shono, Y. and Terashita, M.: Tooth preparation for porcelain laminate veneer Par 3 prediction of labial enamel thickness by radiograph. J. Conserv. Dent. 36: 1109-1114, 1993. (in Japanese)

17) Ferrari, M., Patroni, S. and Balleri, P.: Measurement of enamel thickness in relation to reduction for etched laminate veneers. Int. J. Periodontics Restorative Dent. 12: 407-413, 1992. 


\title{
中国人の上顎前歯における唇側エナメル質の厚さ
}

\author{
陳克 恭 ${ }^{1}$ - 林 偉 傑 ${ }^{2}$-大 木 達 雄 ${ }^{1}$ \\ 石四 筬 ${ }^{2}$ 寺下 正 道 \\ ${ }^{1}$ 九州雬科大学歯科保存学第 1 講座（主任：寺下正道教授) \\ ${ }^{2}$ 同済大学口腔医学院児童口腔医学研究所 (主任: 石 四筬教授)
}

中国人に対するポーセレン・ラミネートべニア修復の 支台歯形成の基準を決めるため, 中華人民共和国上海地 区で集めた中国人上顎中切歯，側切歯および犬歯の唇側 エナメル質の厚さを測定し，エナメル質の削除量の目安 を求めた.

中切歯におけるエナメル質の削除量は日本人の目安と 同じく歯頸側マージン部から最大豊隆部までを $0.3 \mathrm{~mm}$ とし，中央部から切縁までを $0.5 \mathrm{~mm}$ としてょい．しか
し，側切歯と犬霜における雬頸部のエナメル質の厚さは 日本人よりばらつきが大きく, 削除量の許容範囲を $0.25 \mathrm{~mm}$ に設定したほうが象牙質露出の危険性が避け られると思わ机る. 中切霜, 側切歯, 犬歯ともに近心側 エナメル質の厚さと唇側同位置のものとの間に有意な正 の相関が認められたことから, 唇側エナメル質の削除量 はレントゲン写真で判断される近心側エナメル質の厚さ から予測することが可能である。 